\title{
Democracy and Popular Protest in Europe: The Iberian Case
}

\section{Célia Taborda Silva}

Prof. Associate, Universidade Lusófona do Porto

\begin{abstract}
In recent years, Europe has witnessed social movements that break away from the conventional patterns typical of 19th and 20th century movements. The party-or trade union-organised social movements, very much centred on 19th century political and economic issues, or the New Social Movements centred on more universal values such as peace, environment, gender, ethnicity, of the 20th century seem to be changing their 'repertoire'. At the beginning of the 21st century, parties and trade unions have been losing their leading role in the organisation of demonstrations and strikes and collective actions prepared and led by specific actors have given way to new forms of social action, without leaders, without organisation, without headquarters, and which use social networks as a form of mobilisation. These are social movements that contest not to have more rights but to exercise those that exist, a full citizenship that offers the freedom to express one's opinion and the regalia of participation in political, economic, social, educational areas. In Europe, there are various types of such movements, but we will highlight the "Geração à Rasca (Scratch Generation)" movement in Portugal and that of the "Indignados (Outraged)" or 15 M in Spain, both started in 2011, and which had repercussions in the main European capitals. Using a qualitative methodology, through these protest movements we seek to understand how the complexity of today's social movements and their non-institutionalisation represent a challenge to European democracy.
\end{abstract}

Keywords: Democracy, protest, Iberian, challenge, Europe

\section{Introduction}

The post-war democracy made possible an opening for economic and social development and the industrialisation process led society to a profound transformation: the industrial society gave way to the information society and today we speak of a network society (Castells, 1999). Democracy, as a historical process, was the result of many popular protests over time and one of the consequences of the democratic process is the existence of social movements, which may or may not be 
democratic (Tilly, 2004, p.56). However, the relationship between democracy and social movements is not consensual, since these are sometimes considered a threat to democracy, and at other times a symbol of its vitality, of the dynamism of civil society. Digital technologies have reinforced the way in which social movements are viewed. It can be said that social organisation in digital technology networks is a new form of social organisation that transcends the physical territorial spaces of each state and becomes global. This technology has created a generation of internet users who favour this medium to communicate among themselves, thus escaping the channels created by the institutions of society, namely the traditional media, giving rise to "selfcommanded mass communication" (Castells, 2007, p.248). Now, from network communication to the mobilisation of network movements was such a rapid step that European democratic institutional bodies, imbued with the full weight of their tradition of representation and bureaucracy, have difficulty in seeing and understanding the real significance of these movements.

The concept of social movement has evolved as society has been and in the last three decades of the 20th century, authors such as Touraine $(1969,1973,1978)$ and Melucci (1996) understood social movements as a form of sustained collective action, whereby actors sharing identities or solidarities confront dominant social structures or cultural practices. In this way, current social movements (post 2000) have become more complex and analysis little consensual, mobilise in networks and on the margins of institutional mechanisms, question institutional political and party structures, acting on their margins, as happened in Iberian, with the Scratch Generation and 15 $\mathrm{M}$ or "Indignados" but assert themselves as a social actor to the extent that they put democratic governments in dialogue with social movements.

Thus, through a qualitative methodology, using information conveyed in Portuguese and Spanish newspapers about the movements " Scratch Generation " and "Indignados", we seek to understand how the complexity of today's social movements and their non-institutionalization represent a challenge to European democracy.

\section{Analysis: The Iberian Movements}

\subsection{The 'Scratch Generation' movement in Portugal}

It was in the context of economic insecurity and political mistrust in Portugal that the so-called 'Scratch Generation' movement, which campaigned against unemployment and precariousness, was born (Baumgarten, 2013). The movement grew from the challenge launched by young people via social networks and it essentially targeted young people. The promoters of the 'Scratch Generation' were themselves young people, graduates and symbols of the generation, given their status as trainees, fellows or unemployed. They felt angry that their generation was experiencing difficulties becoming economically independent of their parents despite their academic training, and they shared their anxieties with other young people via the internet. They decided to send an open letter to civil society explaining the need to 
address the precarious working conditions in Portugal, where qualifications, skills and experience were not mirrored by salaries and decent contracts, and where they were pejoratively referred to as 'the generation of five hundred euros'. In fact, in their Facebook appeal, they stated, "We, the unemployed, "five-sevens" and other poorly paid, disguised slaves, subcontractors, contractors, false self-employed, intermittent workers, interns, trainees, student workers, students, mothers, parents and children of Portugal, let us express our discontent' (Scratch Generation Protest Blog, 2011). The protest stemmed from the right of all citizens to demand education and employment, an expression of citizenship that was not subsumed by the right to vote, as one young person commented. It was also an affirmation of the young people's distrust in the political system; therefore, they affirmed that the movement was to be 'a nonpartisan, secular and peaceful protest, that tries to reinforce participatory democracy in the country' (Scratch Generation Protest Blog, 2011). Comments and behaviour such as this corroborate the opinion of researchers that 'the most educated young people are more active, have more civic awareness and make more use of citizenship rights' (Ferreira \& Silva, 2005, p. 146).

The aim of the 'Scratch Generation' movement was, according to the promoters, to contribute to 'triggering a qualitative change in the country' (Scratch Generation Protest Blog, 2011. They wanted to find solutions to Portugal's problems and to then be part of those solutions. Lacking prospects for the future and in a profound state of frustration, they felt the need to unite and to manifest in the public sphere their claims to rights that were being withheld.

The lack of employment experienced by this generation of qualified young people was not merely a conjunctural problem, since, due to the massification of higher education, there had been an exponential increase in the number of students during the 1990s (Abrantes, 2003). In fact, the number of students in higher education in Portugal rose from around 11,000 to 60,500 during that decade (Abrantes, 2003), making it increasingly difficult for graduates to enter the labour market. Of course, at the time the movement was launched, this structural issue was the least of the young people's worries.

Thus, on 12th March 2011, at 3 pm, the squares in the main cities of Portugal were filled with 'Scratch Generation' protesters. Demonstrations were held in several centres of portuguese cities, squares and streets that were historically emblematic.

In the capital, Lisbon, the largest demonstration took place on Avenida da Liberdade. Approximately 200,000-500,000 participants (the number varies according to the information source, that is, the police or the organisation itself) protested against the precarious situation in which they lived. Crowds came from all sectors of society, with the number of demonstrators far exceeding the expectations of both the young promoters and the general participants. The demonstration was surprising not just due to the number of participants, but also due to the different age groups that took 
part (Jornal de Notícias, 2011). A few years earlier, this kind of intergenerational union was almost unthinkable in the context of a single protest. Secondary school students took part in several demonstrations against the global tests that had to be passed in order to enrol in university. As a result, the older generations labelled them the 'scratchy generation'. This pejorative labelling was generalised in the society of the time, which created a generational gap that would eventually undo itself, at least momentarily, during the demonstration of 12th March 2011. On that day, acting together and taking part in the same march, were not only those directly affected by the economic crisis (i.e. young people), but also the parents and grandparents of those who were 'unemployed and precarious', who had to continue to financially support children who should have been able to self-sustain. The complaints of the young were also the complaints of their older relatives, since the professional instability experienced by the young resulted in the economic degradation of previous generations. As mentioned in an article in Visão (2011, p. 70), one in five young people aged 25-35 was at that time economically dependent on family. In some cases, even at the age of 40, people reported having no stable salary and so no ability to fund their own house or family (Diário de Notícias, 2011), although many of these people held higher education qualifications. During the last quarter of 2010, the number of unemployed graduates rose to 68,500 , which was equivalent to $11.2 \%$ of all unemployed people (Loureiro, 2012, p. 337). With so many living in such precarious economic circumstances, reports of individual injustices quickly circulated via social media, eventually being transformed into a collective injustice. This was reflected in the posters people held during the demonstration, which featured slogans such as 'Living Communism - Spreading Anarchism', 'Capitalism is Abominable', 'The Country is Scratchy' and 'Scratchiness is Precariousness'. Several politicians also joined the Lisbon march despite it being a non-partisan movement, as did members of rightwing extremist groups, anarchists and members of the LGBT community (Jornal de Notícias, 2011).

The solemn parades of yesteryear, which progressed at a slow and almost reverent pace, have now given way to demonstrations in which music and dance add a certain colour to the event. Although these manifestations of protest in Portugal had a playful component, the spectacularity they exhibited was only modest when compared to the performances seen during other European anti-globalisation mobilisations, in which masks and disguises alluded to a certain subversion of the carnival theme, which gave the events a high level of visibility in traditional media outlets.

As an article in Visão (2011) said of the demonstration seen in Lisbon and which also applied to those in other cities:

It is not only a manifestation, but several: the manifestation of precarious workers, the manifestation of university students with no future, the manifestation of the 
unemployed, the manifestation of pensioners by anticipation, the manifestation of pensioners of 200 euros, the manifestation of the unschooled workers ... (p. 66).

The movement was a collective action driven by individual interests. Each individual spontaneously joined in after reviewing the situation, as, just like the organisers, they felt themselves to be without future prospects. Effectively, they lacked a group goal that would keep them together beyond the circumstances of the moment. As Pinto (2011) notes, they took part in the demonstration: for a future, for a job, for the end of green receipts, out of curiosity or just to see what it was like, for raising the minimum wage, for the father, for the daughter, dancing, singing, applauding, shouting, or even in silence, no one dared to imagine that the voices and words would merge into one message (p. 34).

In recent years, a number of studies have pointed to the distancing of young people from 'traditional' or 'conventional' politics, such as participation in party voting or a party affiliation, and the growing interest among this population in 'unconventional' politics, such as collaboration in organisations or associations and protest actions (Magalhães \& Sanz Moral, 2008, p. 27). The popularity of the 'Scratch Generation' movement with young people may be a sign of the divergence of the institutional politics of the democratic state from popular politics, that is, a demonstration that young people have both civic and political awareness, although they distrust the methods of representative democratic politics.

\subsection{The 15M Movement or "Indignados".}

Two months after the Portuguese movement, in Madrid, the May 152011 demonstration was an example of the challenge that leaderless mobilisations organised through the internet represent for Democracy. Here, as in other European demonstrations, it was through social networks, especially Facebook and Twitter, that there was a mobilisation for the May 15 protest. This year, Spain was immersed in the crisis affecting the Eurozone, unemployment reached 22\% (47\% were young people), and the government, to contain the deficit, promoted cuts in health, education, social service. To make matters worse, the socialist executive approved the Sinde law (control and censorship of information on the Internet), which mobilised some activists to create a digital platform, which they called "Democracía Real Ya" (Real Democracy Now), and to make their discontent known. On the aforementioned networks, Democracía Real Ya called a demonstration for 15 May 2011, a Sunday, exactly seven days before the municipal elections. Through a manifesto they explained the reasons why they were calling on citizens to take to the streets on 15 May. With the emblematic phrase "'we are not merchandise in the hands of politicians and bankers" they tried to attract the attention of internet users to their manifesto.

Then, through a simple and direct text, they touched on the crucial points of collective dissatisfaction. It began like this: "We are ordinary people. We are like you: people who get up in the morning to study, work or look for work, people with families and 
friends. People who work hard every day to live and give a better future to those around them...". They then explained in several items the reasons for their indignation and apprehension, among which they highlighted corruption among politicians, businessmen and bankers, and the absence of a true Democracy, since the political class did not even listen to the people. And they ended: "We are people, not merchandise. I am not only what I buy, why I buy and for whom I buy. For all these reasons I am outraged. I believe I can change. I believe I can help. I know that united we can do it. Come with us. It's your right" (Manifesto Facebook).

This call and the reasons that were given for the demonstration went against the disharmony that hovered in society, especially among the youth, highly qualified, unemployed and without a glimpse of a better future. The same disenchantment popularised Stephane Hessel's book "Indignant", which referred to social inertia in the face of the "international dictatorship of financial markets" and called for a "peaceful insurrection" (Hessel, 2011). This hero of the French resistance to Nazism considered that the worst attitude of citizens was indifference, since it led to inaction and consequently could lead to the loss of acquired rights. Hessel's little book had many readers in Spain, and was perhaps inspirational for the mentors of "Democracia Real Ya" and those who took to the streets on 15 May. On that Sunday, around 130,000 people, according to the organisers, gathered in Madrid at Puerta del Sol, the city's central square to protest. The newspaper El País reported that many of the demonstrators were unemployed poorly paid, subcontracted, mortgaged, outraged by the economic crisis and the resulting social problems (El País, 15 May 2011). Among the most underprivileged were young people, who being supporters of netactivism "new type of action in connected digital networks", (Di Felice, 2012), contributed to the rapid dissemination of the message and the turnout of so many people at the demonstration. The participants, armed with slogans such as "this crisis we are not paying for it", "it is not illegal the voice of the people", or "politicians do not represent us" (El País, 15 May) walked through the main streets and squares in the centre of the capital (Gran Vía, Paseo del Prado, Atocha) and demonstrated their feelings towards governments, banking, the political class, and above all the mismanagement of the crisis by a "dysfunctional and irresponsible political system" (Castells, 2013a, p.90). Through this non-partisan form of organisation they showed their lack of confidence in leaderships, parties and trade unions to represent them, similarly to other European citizens and others. They therefore introduced an innovative form of mobilisation into social movements, although in the street they used the old methods: marches, lectures, posters, to make the reasons for the demonstration visible to the community and the traditional media. In the Spanish capital the demonstration did not end without clashes with the police (El País, 15 May).

The "Indignados" of Madrid were joined by other malcontents who at the same time protested in around 50 cities in Spain, as well as in Portugal, Ireland, Holland, France 
and the United Kingdom. In all countries, historically symbolic places were chosen for the space of representation, sharing and discussion, in a search for community solidarity lost in the anonymity of mobilisation. Once the demonstration was over, a group of indignados from Madrid decided to stay in Puerta Del Sol to reinforce the dimension of their displeasure and discuss the meaning of real Democracy. In the early hours of the 16th, the camp was violently broken up by the police. The repression acted as a rallying factor to call a new camp for that night and for the whole week, until the Sunday of the municipal elections. The Electoral Commission considered the encampments illegal because they did not allow the calm required for democratic reflection (El País, 17 May 2011).

Suddenly, this social movement took on a life of its own and surpassed the aim of the "Democracía Real Ya" platform. From then on, the "encampments", as they became known, either in Puerta del Sol or in other squares, were no longer organised by "Democracía Real Ya". This platform participated in the encampments but together with other collectives, including Attack, Anonymous, No Les Votes, Juventud Sin Futuro. The $15 \mathrm{M}$ or, as it was popularised by the media, "Indignados", ended up becoming another movement from the "encampments" (Elecciones 24, 20 May 2011), with the implementation of a kind of "micropolis" where a micro model of real democracy was experienced.

The exercise of real democracy was carried out during the Spanish "encamped" and in all the encampments that were spread across the main European squares. In these encampments, as in the demonstration, mainly young people participated, although middle-aged and senior people could be

found in them, who shared the concern about the economic, political and social situation, who did not see themselves in political parties or trade unions, and who came together to seek change (Elecciones 24, 20 May 2011). The capitalist economic system had generated the crisis but the politicians defended the financial interests of the banking and bankers more than the interests of those who elected them, the citizens.

These, in turn, found it legitimate to claim their right to be indignant and fight for "a new society that prioritises life rather than protecting economic and political interests" (Elecciones 24, 20 May 2011). In a peaceful and orderly way they tried to implement in the squares where they camped a new social and political organisation, based on community fraternity and a participatory politics.

In a true practice of direct democracy all decisions concerning the camp and its messages outside it were decided in a general assembly.

These assemblies met, as a rule, daily, with around two thousand people. Similar to what happened in the Athenian public square (agora) each citizen standing in the Puerta del Sol, arm in arm, voted on each measure to be taken for the benefit of the 
community. To implement the measures decided in the Assembly they created working committees, autonomous from each other, which dealt with basic issues such as hygiene, safety, communication, to the elaboration of proposals to be submitted to the Assembly, there were also committees for concrete and specific actions: agroecological initiatives, reform of the electoral law, preventing evictions.

There were no leaders, it was a collective but in which each participant was there in an individual capacity, only representing himself. Each person was free to say what they thought or felt, without needing intermediaries, which for Javier Toret (a member of Democracia Real Ya) is a "paradigm shift between citizen and governments, unions and media" (quoted by Castells, 2013a, p.99). We are facing an empowerment of citizens, collective unity concentrates popular strength and gives them power, if only that of visibility, that of spreading their thoughts.

The citizens camped in Madrid's Puerta del Sol drew up a series of proposals that were approved in a general assembly, regarding the change of the electoral law, respect for the basic rights enshrined in the constitution, reform of the working conditions of the political class, tax reform, education, regulation of the markets, participatory and direct democracy, true separation between State and Church, promotion of renewable energies, effective separation of powers, recovery of privatised public companies, reduction of military spending, recovery of historical memory, total transparency in the financing of political parties and their accounts as a means of curbing corruption.

In this movement there was never a formal organisation, with a defined programme; there were proposals, many of them, not only from the Madrid campers but also from those of other cities and countries, although their aim was not to fulfil them immediately. The participants of the "encampments" knew that positioning themselves outside the established institutional system would not make any proposal viable (Castells, 2013b, p.103), but in the long term it could present an alternative, as eventually happened when citizens who participated in the movement formed a new party.

These camps, where they implemented a new democratic model, as they existed in default of the established power could not last long. This exercise in real democracy implied the occupation of public space, and even assuming that it belongs to everyone, it was still seen as an "affront" to the holders of political power, a kind of counterpower. Consequently, the response to this action, on the part of the Spanish government and other European governments where there were encampments, was a ban on staying in the squares, often accompanied by police repression (El País, 3 August 2011). In addition, this occupation brought problems of maintenance of the area itself.

It was not possible to stay indefinitely in the camp because life deteriorated and it began to be the home of the homeless. This circumstance, together with the fact that with the passing of time only young people without family responsibilities could take 
part full-time in the assemblies, began to empty the movement, inside and out, in the eyes of public opinion. Standing meant shrinking crowds and they couldn't risk being reduced to half a dozen camped activists if they wanted to give a voice to the whole population. So at the end of June they lifted the Madrid camp and the others came after. The movement was continued in the neighbourhoods through residents' assemblies, which functioned along the same lines. The assembly was sovereign, leaderless and with independent committees. Its decisions were disseminated over the internet so that they could be debated by everyone. The activists built an "organisational culture" based on values such as diversity, subjectivity, transparency, open confrontation aimed at building consensus and "ideological contamination" in the face of dogmatism (Della Porta, 2005).

Castells considers this movement "essentially political". The sociologist says that "it was a movement for the transformation of a pseudo-democracy into an authentic democracy" (2013a, p.102) and, despite only having assumed this character in the second phase, the truth is that it was the original manifesto which triggered the movement, therefore, which originated its existence.

The novelty of this movement and of the later European movements was, according to Camargo, "the appearance of "tides" in which various sectors joined in protest, claiming their own issues but merging them into a common protest"(Camargo, 2013, p.136). And in this novelty lies a great challenge of the social movements, in that they reached a human and geographical dimension not imaginable in previous movements and put institutional powers into dialogue and attempts to negotiate with noninstitutional actors.

\section{Discussion: the challenge of social movements for European democracy}

The movements of 12 March and 15 May 2011 in the Iberian Peninsula were not isolated cases, they are part of a line of contestation that crossed Europe in crisis. Movements arise for diverse reasons, as we have seen, but the current ones, for Castells, result from the "contradiction and conflicts of specific societies, and express people's revolts and projects resulting from their multidimensional experience" (Castells, 2013a, p.170). For Romanos (2011) in Spain, the 15M movement inaugurated a cycle of protest whose extent and intensity, capacity of convocation and transversality are unprecedented in the recent history of this country.

These Iberian mobilisations follow the wave of transnational mobilisations of indignation that started in North Africa and the Middle East and that network communication has facilitated, making these global movements a challenge for European leaders.

For Bela Irina Castro they represent a "countercultural social contestation movement that seeks to rescue the debate and the political decision into everyday life through the occupation of public spaces" (2012, p.124). 
Social movements have demonstrated citizens' divergence from the liberal political model and capitalist economy governing European states, demanding a less elitist and more participatory politics. The movements that have occupied the squares and streets of Europe appeared spontaneously through mobilisation in social networks, without party or trade union organisation, even rejecting established leaderships. This new form of mobilisation and action seems to refer to the citizens' disagreement with the systems of representation, whether parties or unions, and to the emergence of a global citizenship that shares the desire for a renewed Democracy, and becomes a challenge insofar as the connection in networks leads to an alteration of the social. As Di Felice points out, "net-activism marked the first forms of social conflictualities that through the internet displace social action to a planetary computer spatiality" (2013, p.55). This spatial displacement of action, ease of appearance and expansion in space, makes institutional control difficult and enables the survival of movements such as the "Indignados", as well as the appearance of more demonstrations in the European public space. On the other hand, the internet functions as a protective factor against repression and as a facilitator of widespread communication, not only with the participants/sympathisers of the movement but with the whole of society, and, most importantly, it establishes a connection with the culture of today's societies which, in Castells' opinion, is "the culture of autonomy" (Idem: 171). Citizens claim autonomy from historically constituted institutions, embodied in "a new social contract" (ibid.). This contract is based on the freedom that communication through the Internet grants to its users (Idem, 172). Thus, for this author, "behind the scenes of this process of social change is the cultural transformation of our societies" (idem, ibidem), which is reflected in the will to transform the democratic political process (idem, 113). In the case of the $15 \mathrm{M}$, mistrust of conventional politics brought together people with or without ideology in a non-partisan movement, but with political aims and a reaction to the current political system itself, which is why they are running away from the corporate mechanisms of politics.

Another challenge they pose is that of security, as they break the rules of institutional bodies they cause a certain fear, leading governments to respond with police repression to movements that are presented as peaceful. The current democratic political organisation does not know how to deal with all "this dizzying multiplication of communication, this taking over of the word by a growing number of subcultures" (Vattimo, 1989, p.87). The cultural dimension and that of social change which some researchers have identified in social movements (Goodwin and Jaspers, 2004) are evident in the movements which have recently emerged in Europe. Proof of this is the emergence of new political forces such as "Podemos" in Spain or "Syriza" in Greece.

Does this mean that social movements are leading us towards the construction of a European public sphere? The answer to this question already takes us into the sphere of European political contestation. According to Della Porta and Caiani, there are several obstacles to the Europeanisation of political conflict: the low visibility of the 
EU in political terms; the enormous power of corporate and institutional actors; a certain isolation of NGOs from political networks; the high cost of transnational mobilisations; or even the predominance of organisations historically anchored in the nation-state. For the above-mentioned authors, European collective action will have to involve the union of social actors, in the sense of stimulating common identity. However, this may not be such a far-off challenge for the European Union, given the protests of the last four years. The crisis situation has highlighted similar problems and struggles among citizens of the various EU nation states, which has contributed to a strengthening of identities, especially among those most disadvantaged by social policies (Della Porta and Caiani, 2009).

To conclude, we understand, like Gohn, that the fact that these demonstrations are part of a "new form of social movement composed predominantly of young people, educated, connected by and in digital networks, horizontally organised, critical of traditional ways of doing politics" (2014) becomes the biggest challenge of social movements for the European space, because they call into question this model of representative democracy.

\section{Conclusion}

The collective actions currently taking place in the streets pose European democratic governments the challenges of dealing with large-scale movements, operating in networks but spontaneous in appearance, mobilised through the internet, and of seeing the urban public space occupied by movements not organised by parties or trade unions, outside institutional formalism and state control.

As in previous centuries, social movements reflect the society in which they are embedded. If today technology has made available to individuals the opportunity to be both actor and receiver of information, the possibility to become visible without intermediaries, this technique is naturally harnessed for the promotion of social discontent, as once were the traditional media, especially newspapers. Despite all the technology, we think that it is in the streets and not in the networks that movements are challenging democracies as promoters of social and political change. It was the social problems that brought people to the streets and not Facebook or Twitter, because if there was no dissatisfaction, injustice and social inequality there would be no place for these protests. We have the Iberian examples analysed here, in particular the "Indignados". It was their permanence on the streets that allowed them to create complicity,

It was their presence on the streets that enabled them to create complicity, discover idiosyncrasies, make suggestions, leading some of the elements that made up the $15 \mathrm{M}$ (although already disconnected from the movement) to move forward with proposals of a political nature. And, as in the past, political power only adapts to the changes demanded by society through contestation. However, it should be noted that this protest movements, which has manifested itself in unison within Europe, does not 
reflect a desire for a single government in the European Union; on the contrary, one of the criticisms expressed in these demonstrations by citizens was the subservience of nation states to the European Union. This means that these protests are still nationally oriented, reflecting more an internalisation than an externalisation of European collective action.

\section{References}

[1] Abrantes, P. (2003). Identidades juvenis e dinâmicas de escolaridade. Sociologia - Problemas e Práticas, 41, 93-115.

[2] Baumgarten, B. (2013). Geração à Rasca and beyond. Mobilizations in Portugal after 12 March 2011. Current Sociology, 61(4), 457-473.

[3] Camargo, J. (2013), Que se Lixe a Troika!. Porto: Deriva Editores.

[4] Castells, M. (1999). A Era da Informação: Economia, Sociedade e Cultura - A Sociedade em Rede. São Paulo: Paz e Terra.

[5] Castells, M. (2007). Communication, Power and Counter-power. International Journal of Communication 1, 238-266.

[6] Castells, M. (2013a). Redes de Indignação e Esperança. Movimentos Sociais na era da internet. Rio de Janeiro: Zahar editores.

[7] Castells, M. (2013b). A Sociedade em Rede. Do conhecimento à ação política. In Castells, M. e Cardoso, G. (org ). A Sociedade em Rede. Do conhecimento à ação política. Lisboa: Casa da Moeda, pp.17-31.

[8] Castro, B.I. (2012). "Indignados". In Dicionário das crises e alternativas. Coimbra: Almedina.

[9] Della Porta, D. (2005). "Making the Polis: Social Forums and Democracy in the Global Justice Movement", Mobilization, vol. 10, no. 1, 73-94.

[10] Della Porta, D. (2009). Social movements and Europeanization. Oxford: Oxford University Press.

[11] Di Felice, M. (2012). Paisagens pós-urbanas. Lisboa: Vega.

[12] Di Felice, M. (2013). Ser Redes: o formismo digital dos movimentos netativistas. Matrizes. Ano 7 - no 2, jul./dez, 49-71.

[13] Ferreira, P.M. \& Silva, P.A. (2005). O Associativismo Juvenil e a Cidadania Política. Lisboa: Instituto de Ciências Sociais da Universidade de Lisboa.

[14] Gohn, M. G. (2014). Manifestações de Junho de 2013 no Brasil e praças dos Indignados no Mundo. Pétropolis: Vozes.

[15] Goodwin, J., Jasper, J. (Eds,). (2004). Rethinking social movements. Structure, meaning and emotion. Lanham: Rowman \& Littlefield.

[16] Hessel, S. (2011). Indignai-vos! Carnaxide: Ed.Objectiva.

[17] Magalhães, P. \& Sanz Moral, J. (2008). Os jovens e a política. Lisboa: Centro de Sondagens e Estudos de Opinião da Universidade Católica Portuguesa.

[18] Loureiro, L. (2011). O Ecrã de Identificação. Tese de Doutoramento em Ciências da Comunicação. Especialidade em Sociologia da Comunicação e da Informação. Universidade do Minho, Braga. 
[19] Mellucci, A. (1996). Challenging codes - collective action in the information age. Cambridge: University Press of Cambridge.

[20] Pinto, M. \& Sousa, H. (2011). Foreword, in M. Pinto e H. Sousa (eds.), Communication and Citizenship - Rethinking crisis and change, Coimbra: Grácio Editor.

[21] Romanos, E. (2011). El 15M y la democracia de los movimientos sociales. La vie des idées. https://booksandideas.net/El-15M-y-la-democracia-delos.html

[22] Tilly, C. (2004), Social Movements: 1768 - 2004. London: Paradigm Publishers.

[23] Touraine, A. (1969). La societé post-industrielle: naissance d'une societé. Paris: Ed.Denoel.

[24] Touraine, A. (1973). Prodution de la societé. Paris:Seuil.

[25] Touraine, A. (1978). La voix et le regard: Sociologie des movements sociaux. Paris: seuil.

[26] Vattimo,G. (1989). A sociedade transparente. Lisboa: Relógio d'agua. 